\title{
PENGARUH JENIS DAN WARNA UMPAN BUATAN RAWAI TEGAK TERHADAP HASIL TANGKAPAN IKAN PELAGIS KECIL
}

\author{
The Influence of Type And Color of Artificial Bait Vertical Longline on small pelagic fish catches
}

\author{
Oleh : \\ Ricky Winrison Fuah ${ }^{1 *}$, Diniah ${ }^{1}$, Gondo Puspito ${ }^{1}$ \\ ${ }^{1}$ Program Studi Teknologi Perikanan Laut, Dept. PSP-FPIK, IPB \\ *Korespondensi: rickyfuah9@gmail.com
}

\begin{abstract}
ABSTRAK
Salah satu faktor penentuan keberhasilan dalam penangkapan menggunakan rawai tegak adalah umpan, baik umpan buatan maupun alami. Umpan berfungsi untuk menarik perhatian ikan sasaran sehingga ikan tersebut tertarik untuk memakan atau mengigitnya. Umpan yang digunakan dalam uji coba adalah karet pentil dan kain kaca warna merah dan kuning. Tujuan penelitian ini yaitu untuk menentukan jenis dan warna umpan yang tepat untuk menangkap ikan pelagis kecil terbanyak. Metode penelitian yang digunakan adalah experimental fishing, dengan metode analisis data uji normalitas Kolmogorov-Smirnov dan uji Mann-Whitney. Jumlah responden 12 orang. Hasil penelitian diperoleh penggunaan karet pentil menangkap 4 spesies terbanyak yaitu Selar crumenophthalmus 1.813 ekor, Decapterus russelli 991 ekor, Decapterus tabl 973 ekor, Selaroides leptolepis 1.311 ekor, sedangkan menggunakan kain kaca menangkap 1 spesies terbanyak yaitu Rastrelliger faughni 1.295 ekor. Kesimpulannya yaitu karet pentil lebih baik untuk menangkap famili Carangidae sedangkan kain kaca lebih tepat untuk menangkap famili Scombridae.
\end{abstract}

Kata Kunci : Carangidae, kain kaca, karet pentil, scombridae, umpan buatan

\begin{abstract}
One factor determining success in catching using vertical longline is bait, both artificial and natural baits. Bait works to attract the attention of the target fish so that the fish interested to eat or bite it. The baits used in the trial were red and yellow valves and fabric organza. The purpose of this study is to determine the type and color of the baits which are right for catching the most small pelagic fish. The research methods used was experimental fishing, with the method of analyzing the Kolmogorov-Smirnov normality test and the Mann-Whitney test. The number of respondents is 12 people. From the results of this study, it was found that valve caught 4 most species those are Selar crumenophthalmus 1,813 tails, Decapterus russelli 991 tails, Decapterus tabl 973 tails, Selaroides leptolepis 1,311 tails, while using fabric organza caught the most species, Rastrelliger faughni 1,295 tails. In conclusion, the valve is better for capturing the Carangidae family while the fabric organza is more appropriate for catching the Scombridae family.
\end{abstract}

Key words : Carangidae, fabric organza, valve, scombridae, artificial bait

\section{PENDAHULUAN}

Selat Semau merupakan salah satu perairan yang terletak di Kabupaten Kupang yang memiliki sumberdaya ikan cukup melimpah. Menurut Ataupah (2010), sumberdaya ikan yang terdapat di perairan tersebut diantaranya pelagis kecil, pelagis besar, ikan karang dan ikan demersal. Pelagis kecil merupakan sumberdaya yang paling banyak tertangkap di Selat Semau (BPS Kabupaten Kupang 2016). 
Salah satu kelompok nelayan yang menangkap ikan pelagis kecil di selat Semau adalah nelayan Tablolong. Alat tangkap yang paling banyak digunakan adalah rawai tegak (vertical longline).

Rawai tegak (vertical longline) adalah satu jenis alat penangkapan ikan yang menggunakan mata pancing dengan atau tanpa umpan (Sadhori, 1984). Mata pancing dikaitkan pada tali pancing dan dioperasikan menggunakan tenaga manusia (Sudirman dan Mallawa, 2012). Selain itu konstruksinya sangat sederhana dan pengoperasiannya juga tidak memerlukan modal yang besar.

Konstruksi rawai tegak (vertical longline) terdiri dari satu tali utama dan beberapa tali cabang yang dipasangi sejumlah mata pancing. Mata pancing dipasang langsung pada tali cabang yang diikatkan pada tali utama (Ardidja, 2011). Pengoperasian alat penangkapan ikan rawai tegak dengan cara menurunkannya ke dalam perairan dimulai dari tali utama, tali cabang dan sejumlah mata pancing yang sudah diberi umpan, baik itu umpan alami maupun umpan buatan (Puspito, 2009).

Faktor utama dalam keberhasilan pengoperasian alat tangkap rawai tegak adalah ukuran dan bentuk mata pancing serta berbagai jenis umpan baik umpan alami maupun umpan buatan (Kurnia et al. 2015). Ukuran mata pancing memiliki peranan yang penting dalam tingkat keberhasilan rawai tegak, dimana dapat menentukan besar kecilnya ikan hasil tangkapan yang tertangkap (Azizah dan Puspito, 2012), sedangkan umpan berfungsi untuk menarik perhatian ikan sasaran sehingga ikan tersebut tertarik untuk memakan atau mengigitnya (Subani dan Barus, 1989 dalam Riyanto, 2008).

Umpan yang digunakan oleh nelayan Tablolong pada rawai tegak berupa umpan buatan karet pentil dan kain kaca dengan warna yang berbeda pula yaitu merah dan kuning. Penggunaan kedua jenis dan warna umpan tersebut didasarkan pada kebiasaan nelayan turun-temurun dan pengetahuan nelayan yang sangat terbatas, sehingga nelayan pada umumnya belum mengetahui secara pasti jenis dan warna umpan buatan mana yang dapat menghasilkan jumlah ikan pelagis kecil terbanyak. Hal ini membuat nelayan setempat selalu mengganti penggunaan jenis dan warna umpan berdasarkan pada naluri masing-masing, sehingga hasil tangkapan yang diperoleh pun seringkali tidak memuaskan bagi nelayan. Sehingga perlu dilakukan penelitian terhadap penggunaan umpan yang digunakan oleh nelayan, agar dapat menentukan umpan yang terbaik dalam menangkap ikan pelagis kecil.

Penelitian berkaitan dengan umpan sudah banyak dilakukan sebelumnya, seperti penelitian (Paransa et al. 2014; Anggriawan et al. 2018; Azizah dan Puspito, 2012; Hsieh et al. 2001; Siswoko et al. 2013; Usili et al. 2015), namun masih secara spasial atau tidak secara spesifik untuk menangkap ikan pelagis kecil. Selain itu penelitian serupa belum dilakukan pada tempat penelitian yaitu Selat Semau, sehingga perlu dilakukan penelitian mengenai uji coba terhadap jenis dan warna umpan buatan yang digunakan oleh nelayan Tablolong. Tujuan dari penelitian ini yaitu untuk menentukan jenis dan warna umpan yang terbaik dalam menangkap ikan pelagis kecil.

\section{METODE PENELITIAN}

Penelitian dilakukan langsung di perairan Selat Semau, Kabupaten Kupang, Nusa Tenggara Timur (Gambar 1) dengan mengoperasikan rawai tegak menggunakan metode percobaan. Penelitian ini berlangsung selama 7 hari pada bulan September 2018. Alat tangkap yang digunakan adalah rawai tegak berjumlah 12 unit alat tangkap, dimana terdiri dari 4 unit rawai tegak menggunakan pancing nomor 18 (kontrol), 4 unit menggunakan pancing nomor 16, dan 4 unit menggunakan pancing nomor 15. Setiap unit alat tangkap dilengkapi dengan jenis (karet pentil dan kain kaca) dan warna umpan buatan (merah dan kuning). 


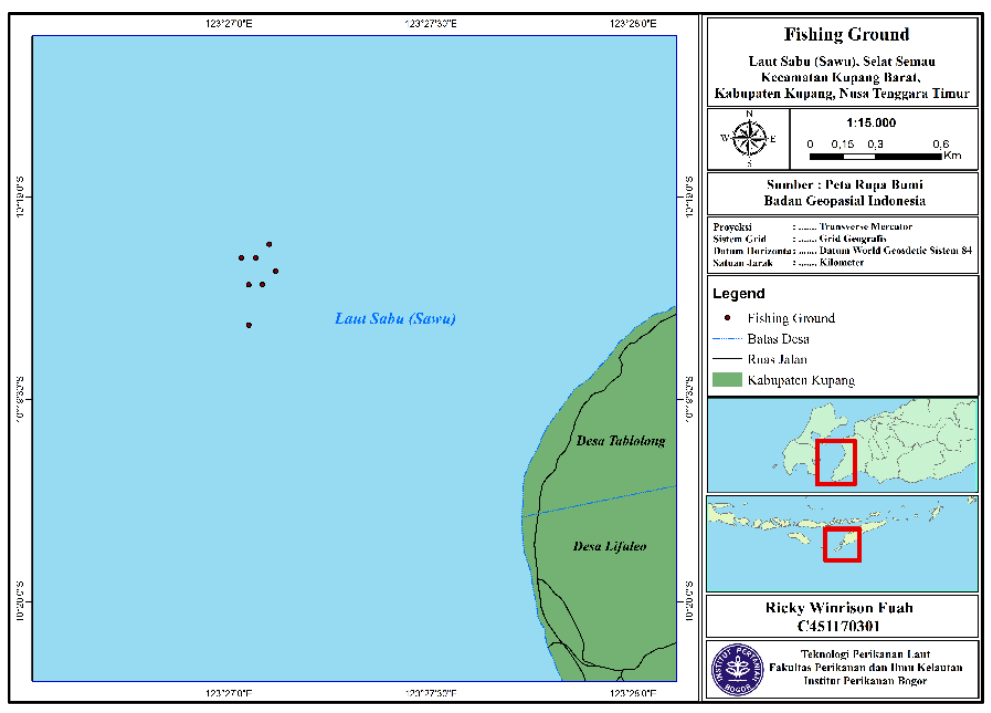

Gambar 1 Peta daerah penangkapan

Rawai tegak yang digunakan memiliki bagian-bagian antara lain tali utama (main line) dengan panjang $150 \mathrm{~m}$, tali cabang (branch line) dengan panjang $30 \mathrm{~cm}$. Jarak pemasangan antar tali cabang adalah $150 \mathrm{~cm}$. Dalam satu tali utama terdiri dari 20 tali cabang yang ujungnya diberi mata pancing. Mata pancing yang digunakan adalah mata pancing biasa ( $\mathrm{hook}$ ) nomor 18,16 dan 15 . Jumlah mata pancing pada satu unit rawai yaitu 20 mata pancing. Setiap mata pancing dipasang umpan buatan karet pentil dan kain kaca. Bagian berikutnya adalah kili-kili (swivel) dan pemberat (sinker). Konstruksi dan spesifikasi dari rawai tegak dapat dilihat pada Gambar 2.

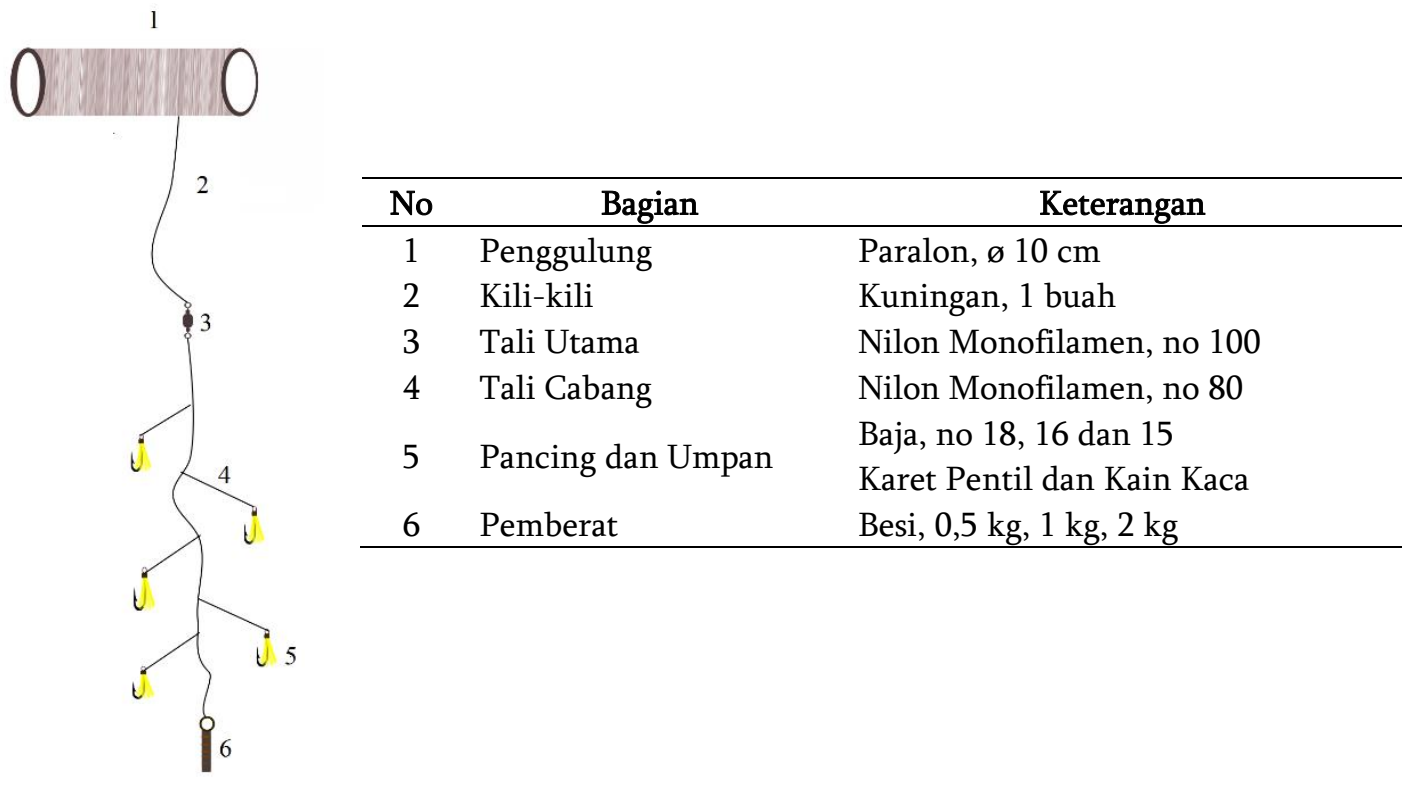

Gambar 2 Konstruksi dan spesifikasi rawai tegak

Kegiatan pemancingan menggunakan satu unit kapal dengan ukuran (14,5 m x 1,42 m x 1,3 m) dan 12 orang nelayan dimana setiap nelayan mengoperasikan masing-masing alat tangkap. Jarak antara nelayan satu dengan yang lain adalah $1 \mathrm{~m}$ pada setiap sisi kapal baik sisi kanan kapal maupun sisi kiri kapal dari bagian haluan sampai buritan. Nelayan yang mengoperasikan alat tangkap merupakan nelayan yang sangat berpengalaman dalam bidangnya (nelayan rawai tegak). Posisi dari nelayan di atas kapal dapat ditunjukan pada Gambar 3. 
Prosedur pengoperasian rawai tegak terdiri dari beberapa tahap diantaranya: (1) Setiap nelayan menggunakan satu unit alat tangkap; (2) Operasi penangkapan dilakukan dari pukul 09.00-15.00 WITA (6 jam operasi/trip); (3) Waktu digunakan sebagai ulangan; (4) Setiap 30 menit dianggap sebagai penanda pergantian ulangan (12 kali ulangan/trip); (5) Posisi pemancing dipertukarkan setiap harinya.

Ikan hasil tangkapan akan digolongkan berdasarkan ukuran mata pancing dan jenis umpan. Selanjutnya akan dilakukan pengukuran panjang total (TL) ikan hasil tangkapan (Sparre dan Venema, 1998) setiap 30 menit sekali.
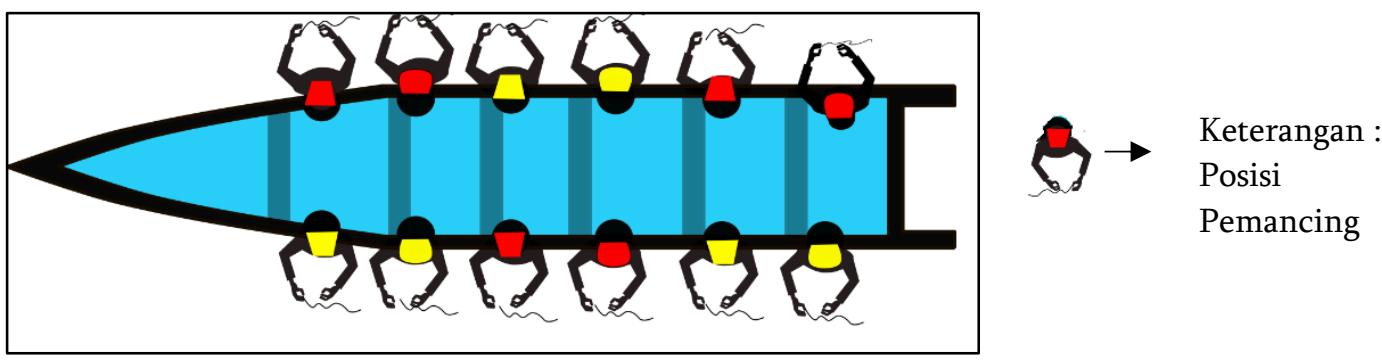

Gambar 3 Posisi pemancing di atas kapal

Data hasil tangkapan yang dikumpulkan yaitu jumlah hasil tangkapan. Selanjutnya akan diplotkan dalam bentuk diagram dan dibandingkan berdasarkan jenis dan warna umpan yang digunakan. Kemudian data akan dilakukan analisis menggunakan uji normalitas Kolmogorov-Smirnov untuk mencari kenormalan data tersebut, jika data tersebar normal akan dilanjutkan uji Anova, namun jika data tidak tersebar normal makan akan dianalisis menggunakan uji non-parametrik yaitu uji MannWhitney. (Usman dan Akbar 2008).

\section{HASIL DAN PEMBAHASAN}

\section{Komposisi Hasil Tangkapan}

Hasil tangkapan yang diperoleh selama uji coba penangkapan ikan dengan menggunakan rawai tegak merupakan ikan pelagis kecil yang memiliki ekonomis penting. Spesies yang tertangkap adalah 5 spesies yaitu ikan kembung (Rastrelliger faughni), selar bentong (Selar crumenophthalmus), layang (Decapterus russelli), layang ekor merah (Decapterus tabl), dan selar kuning (Selaroides leptolepis). Jumlah total hasil tangkapan rawai tegak mencapai 10.285 individu, dengan rincian ikan kembung sebanyak 1.831 ekor (18\%), selar bentong sebanyak 3.072 ekor (30\%), layang sebanyak 1.682 ekor (16\%), layang ekor merah sebanyak 1.645 ekor (16\%) dan selar kuning sebanyak 2.055 ekor (20\%). Data komposisi hasil tangkapan disajikan pada Gambar 4.

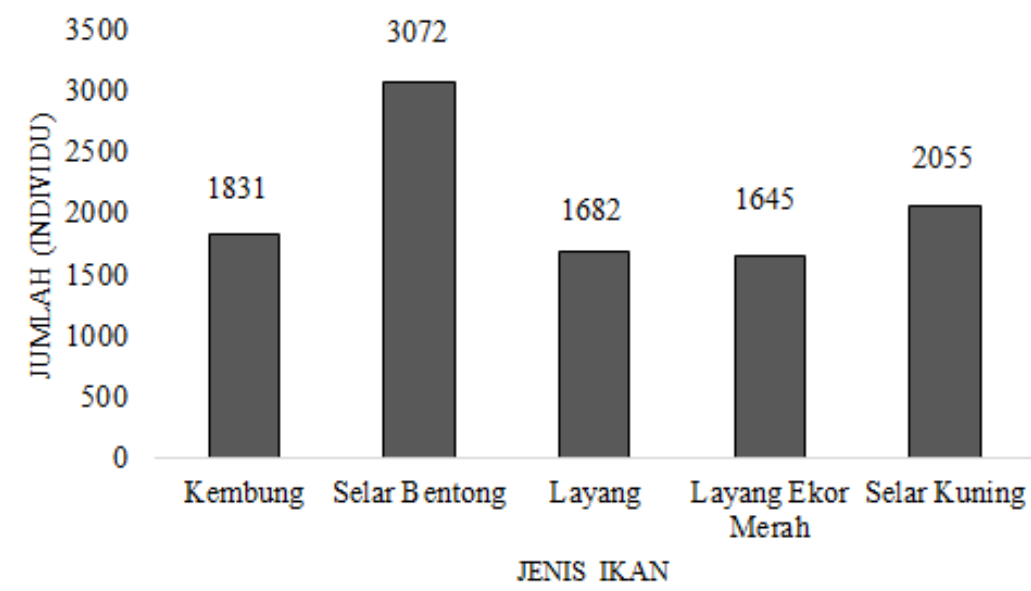

Gambar 4 Komposisi hasil tangkapan 
Berdasarkan gambar di atas, ikan pelagis kecil yang dominan tertangkap pada saat melakukan uji coba penangkapan dengan alat tangkap rawai tegak adalah ikan selar bentong, kemudian diikuti dengan ikan selar kuning, ikan kembung, ikan layng dan terakhir ikan layang ekor merah. Hal ini berbanding lurus dengan pernyataan dari Anonim (2011) bahwa ikan selar dan kembung paling dominan tertangkap di daerah Selat Semau (Kupang Barat), sedangkan ikan layang paling dominan tertangkap di daerah (Kupang Tengah). Menurut Prihartini (2006) ikan layang dominan tertangkap di daerah NTT adalah di Laut Flores jika dibandingkan dengan di Laut Sawu khususnya di Selat Semau.

\section{Komposisi Hasil Tangkapan Berdasarkan Jenis Umpan}

Hasil tangkapan yang diperoleh menurut jenis umpan buatan dapat dilihat pada Gambar 5. Umpan buatan yang digunakan dalam penelitian adalah karet pentil dan kain kaca. Ikan kembung yang tertangkap pada saat penelitian jika dengan menggunakan umpan karet pentil sebanyak 536 ekor dan 1.295 ekor saat menggunakan umpan kain kaca. Untuk ikan selar bentong, pada saat menggunakan umpan karet pentil berjumlah 1.813 ekor dan berjumlah 1.259 ekor pada saat menggunakan umpan kain kaca. Ikan layang yang tertangkap menggunakan umpan karet pentil berjumlah 991 ekor dan menggunakan umpan kain kaca berjumlah 691 ekor. Untuk ikan layang ekor merah, 973 ekor ditangkap pada saat menggunakan umpan karet pentil dan 672 ekor pada saat menggunakan umpan kain kaca. Sedangkan ikan selar yang tertangkap menggunakan umpan karet pentil sebanyak 1.311 ekor dan kain kaca sebanyak 744 ekor.

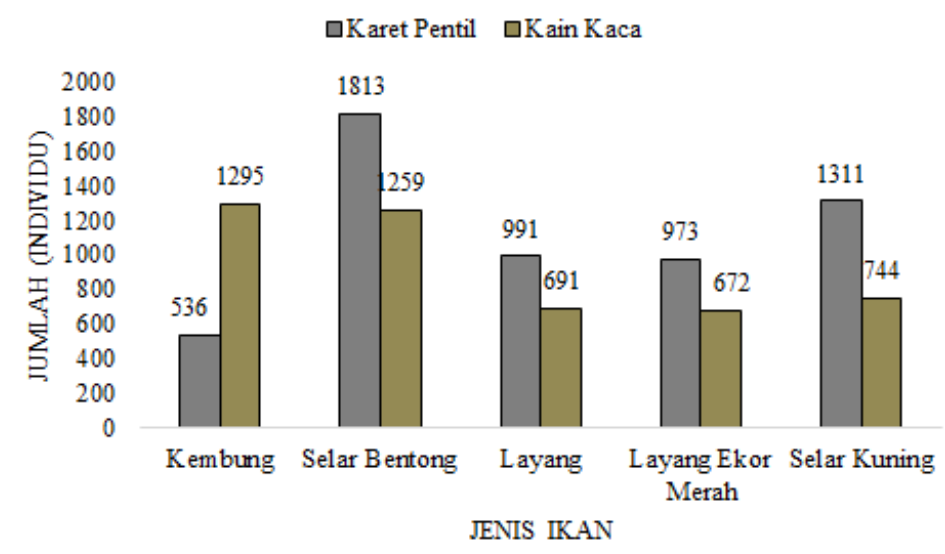

Gambar 5 Jumlah hasil tangkapan berdasarkan jenis umpan

Berdasarkan gambar tersebut dapat disimpulkan bahwa penggunaan kedua jenis umpan buatan tersebut memiliki perbedaan dalam menangkap spesies target. Umpan karet pentil lebih dominan dan tepat digunakan untuk menangkap 4 spesies diantaranya ikan selar bentong, layang, layang ekor merah dan selar kuning. Sedangkan umpan kain kaca lebih tepat digunakan untuk menangkap ikan kembung, hal ini diduga karena setiap umpan tersebut dibuat sedemikian rupa sehingga dapat menyerupai dan mewakili jenis makanan dari ikan target. Contohnya umpan karet pentil yang dipasang sedemikian rupa menyerupai ikan kecil yang merupakan makan utama dari ikan selar dan layang. Umpan kain kaca juga dirangkai dan dipasang sedemikian rupa menyerupai makanan utama dari ikan kembung yaitu plankton. Selaras dengan Kaswadji et al(2009) menjelaskan bahwa makanan dari ikan selar adalah ikan kecil (karnivora), ikan layang dan kembung tergolong omnivora, namun ikan layang lebih banyak memakan ikan kecil, sedangkan kembung lebih menyukai fitoplankton dan zooplankton. Menurut Bubun et al (2014) dan Utami et al (2014) ikan kembung lebih menyukai fitoplankton dan zooplankton sedangkan ikan selar lebih menyukai ikan kecil.

\section{Komposisi Hasil Tangkapan Berdasarkan Warna Umpan}

Hasil tangkapan ikan pelagis kecil menurut warna umpan yang digunakan yiatu warna merah dan kuning hampir tidak memiliki perbedaaan dalam jumlahnya. Hal ini dapat dilihat pada Gambar 6, 
dimana untuk ikan kembung yang tertangkap antara warna merah dan kuning yaitu 937 ekor dan 894 ekor. Untuk ikan selar bentong, diperoleh 1.578 ekor untuk warna merah dan 1.494 ekor untuk warna kuning. Ikan layang, untuk warna merah berjumlah 849 ekor dan warna kuning 833 ekor. Ikan layang ekor merah, pada saat menggunakan umpan warna merah berjumlah 835 ekor dan 810 ekor untuk warna kuning. Sedangkan untuk ikan selar kuning, 1.021 ekor untuk umpan warna merah dan 1.034 untuk umpan warna kuning.

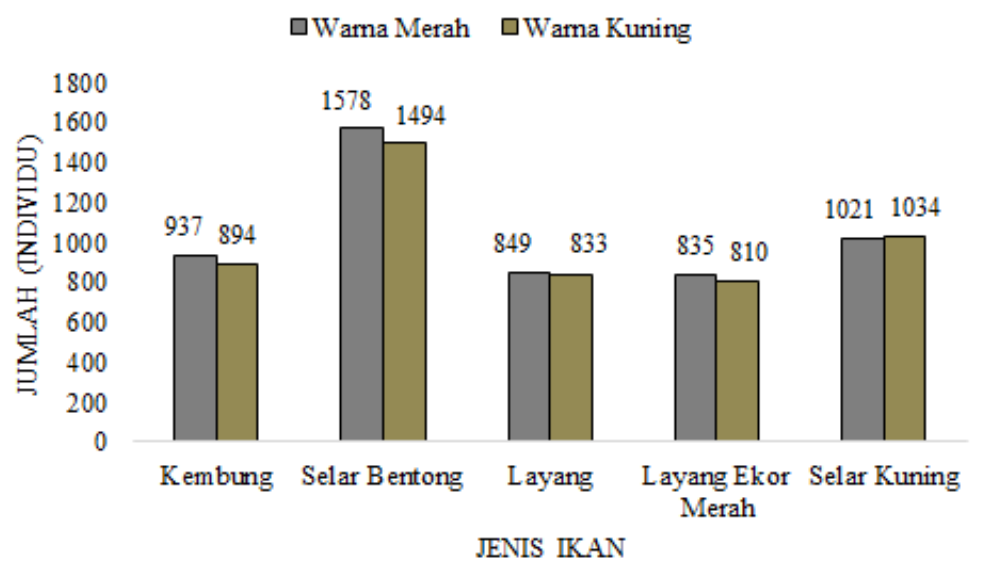

Gambar 6 Jumlah hasil tangkapan berdasarkan warna umpan

Berdasarkan gambar di atas, dapat disimpulkan bahwa sebaran jumlah hasil tangkapan ikan pelagis kecil menurut warna umpan hampir sama banyak, hal ini diduga bahwa kedua warna tersebut sangat disukai oleh ikan pelagis kecil pada umumnya. Selain itu pada saat penelitian, kedalaman saat operasi penangkapan ikan dengan rawai tegak mencapai 75 meter, dimana merupakan kedalaman yang tidak dapat ditembus oleh warna merah dan kuning (Joseph et al, 2017) sehingga ikan tidak dapat membedakan antara kedua warna tersebut. Hal ini diduga menyebabkan ikan akan memakan umpan tanpa membedakan warna.

\section{Uji Normalitas}

Berdasarkan data yang telah diuji menggunakan One-Sample Kolmogorov-Smirnov Test dari hipotesis yang ada menunjukkan nilai signifikansi Kolmogorov-Smirnov untuk perlakuan jenis umpan sebesar 0,000, dan nilai signifikansi Kolmogorov-Smirnov untuk perlakuan warna umpan sebesar 0,000.

Dari uji Kolmogorov-Smirnov di atas menunjukkan bahwa untuk semua perlakuan baik ukuran mata pancing, jenis umpan dan warna umpan memiliki nilai signifikansi 0,000. Nilai ini berada di bawah atau lebih kecil dari taraf signifikansi 0,05, maka dapat disimpulkan bahwa data hasil tangkapan dari semua perlakuan mempunyai sebaran data yang tidak normal. Hal ini mengacu pada pengambilan keputusan yang ada pada metode Kolmogorov-Smirnov dimana jika Asymp. Sig < 0,05 maka sebaran data tersebut tidak normal sedangkan jika Asymp. Sig > 0,05 maka sebaran data tersebut normal (Usman dan Akbar 2008).

\section{Pengaruh jenis umpan terhadap jumlah hasil tangkapan}

Penangkapan ikan dengan menggunakan alat tangkap pancing baik itu rawai horisontal dan rawai vertikal pada umumnya menggunakan umpan. Umpan merupakan salah satu faktor yang sangat penting dalam keberhasilan penangkapan dengan menggunakan alat tangkap pancing. Umpan yang digunakan sangat bervariasi dimulai dari umpan hidup, umpan mati bahkan umpan buatan. Berbagai bentuk dan jenis umpan yang digunakan karena disesuaikan dengan jenis makanan dari ikan target.

Umpan yang digunakan dalam penelitian yaitu jenis umpan buatan yang terdiri dari dua bahan yaitu karet pentil dan kain kaca. Penggunaan kedua jenis umpan tersebut mengikuti kebiasaan nelayan setempat yang selalu menggunakannya untuk menangkap ikan pelagis kecil. Selain itu kedua jenis 
umpan ini digunakan dalam penelitian dikarenakan memiliki tujuan untuk mencari pengaruh dari kedua jenis umpan tersebut, dimana nelayan setempat masih belum mengetahui secara pasti jenis umpan mana yang paling banyak menghasilkan hasil tangkapan, khususnya ikan pelagis kecil.

Berdasarkan hasil analisis menggunakan uji Mann-Whitney dimana untuk mencari perbedaan antara kedua jenis umpan tersebut terhadap jumlah hasil tangkapan, diperoleh nilai Asymp. Sig $<0,05$ untuk semua spesies yang tertangkap, maka dapat disimpulkan bahwa kedua umpan buatan tersebut memiliki perbedaan dalam menangkap jumlah ikan pelagis kecil. Hal ini mengacu dari pengambilan keputusan yang ada pada metode Mann-Whitney dimana jika Asymp. Sig $<0,05$ maka ada perbedaan sedangkan jika Asymp. Sig > 0,05 maka tidak ada perbedaan (Supranto 2001).

Seperti yang sudah dijelaskan sebelumnya bahwa penggunaan jenis umpan disesuaikan dengan kebiasaan makan dan makanan dari ikan target, hal ini juga terbukti dalam penelitian yang telah dilakukan. Umpan karet pentil lebih tepat atau cocok digunakan untuk menangkap ikan selar bentong, selar kuning, layang dan layang ekor kuning, sedangkan umpan kain kaca lebih tepat digunakan untuk menangkap ikan kembung, hal ini disebabkan karena karet pentil dibuat sedemikian rupa sehingga menyerupai makanan dari keempat spesies tersebut, yaitu ikan-ikan kecil dan krustasea, namun kain kaca lebih dirangkai sedemikian rupa menyerupai makanan dari ikan kembung yaitu plankton.

Hasil penelitian yang sama dan mendukung hasil penelitian ini diantaranya Poojary et al (2010) menyebutkan bahwa ikan layang (Decapterus $s p$ ) lebih menyukai krustasea dan ikan-ikan kecil. Pratiwi et al (2016) menjelaskan bahwa ikan selar kuning (Selaroides leptolepis) menyukai ikan-ikan kecil dan zooplankton. Sangadji (2014) juga mengungkapkan bahwa ikan selar bentong (Selar crumenophthalmus) menyukai ikan-ikan kecil. Hal yang demikian pun mengenai makanan dari ikan kembung (Rastrelliger kanagurta) yaitu plankton baik itu fitoplankton maupun zooplankton (Madhavi dan Lakshmi 2011; Asma dan Hismayasari 2013; Hulkoti et al 2013; Bhendarkar et al 2014; Hakimelahi et al 2018)

\section{Pengaruh warna umpan buatan terhadap jumlah hasil tangkapan}

Warna umpan buatan merupakan salah satu komponen yang tidak dapat dipisahkan dari faktor penentu keberhasilan dalam penangkapan ikan dengan menggunakan alat tangkap pancing. Penggunaan warna umpan lebih diutamakan untuk memberikan pengaruh terhadap penglihatan dari ikan target. Berbagai jenis warna umpan sering digunakan dalam penelitian-penelitian, terutama penggunaan warna pada umpan buatan, hal ini dimaksudkan agar dapat memberikan pengaruh bagi penglihatan ikan, karena umpan buatan biasanya tidak memiliki ciri khusus seperti umpan hidup pada umumnya yaitu bau.

Penelitian yang telah dilakukan menggunakan warna merah dan kuning. Kedua warna tersebut digunakan karena mengikuti kebiasaan nelayan setempat yang selalu menggunakan warna tersebut. Percobaan terhadap kedua warna tersebut juga dikarekan nelayan setempat masih belum mengetahui secara pasti warna mana yang paling banyak menghasilkan jumlah ikan target terbanyak.

Berdasarkan hasil analisis uji Mann-Whitney dimana untuk mencari perbedaan antara kedua jenis warna umpan tersebut terhadap jumlah hasil tangkapan, diperoleh nilai Asymp. Sig > 0,05 untuk semua spesies yang tertangkap, maka dapat disimpulkan bahwa kedua warna umpan buatan tersebut tidak memiliki perbedaan dalam menangkap jumlah ikan pelagis kecil. Hal ini mengacu dari pengambilan keputusan yang ada pada metode Mann-Whitney dimana jika Asymp. Sig < 0,05 maka ada perbedaan sedangkan jika Asymp. Sig > 0,05 maka tidak ada perbedaan (Supranto 2001). Untuk warna umpan merah mengahsilkan jumlah ikan sebanyak 5.220 ekor dan warna umpan kuning menghasilkan jumlah ikan sebanyak 5.065 ekor untuk semua spesies yang tertangkap.

Tidak adanya perbedaan dalam jumlah hasil tangkapan berdasarkan warna umpan buatan yang digunakan dalam penelitian dikarenakan warna merah dan kuning merupakan warna yang memiliki panjang gelombang yang tinggi, dimana merah yaitu 620-750 nm sedangkan kuning yaitu 570-590 nm. 
Jayanto et al (2015) menjelaskan bahwa warna yang memiliki panjang gelombang tinggi cenderung memiliki intensitas perpendaran yang lebih kecil jika dibandingkan dengan warna yang memiliki panjang gelombang yang pendek. Penpendaran intensitas yang kecil akan mempengaruhi penetrasi dari cahaya tersebut tidak dapat menembus sampai pada kedalaman perairan, sehingga ikan tidak dapat melihat atau membedakan warna tersebut. Hal ini yang menyebabkan jumlah hasil tangkapan pada kedua warna tersebut tidak berbeda nyata.

Berdasarkan penelitian yang dilakukan oleh Hsieh et al (2001) dan Usili et al (2015), warna merah dan warna kuning tidak memiliki perbedaan yang signifikan terhadap hasil tangkapan atau hasilnya sama. Southwood et al (2008) mengungkapkan bahwa ikan pelagis baik itu pelagis kecil maupun pelagis besar cenderung menyukai atau tertarik pada warna yang memiliki panjang gelombang rendah. Sedangkan Joseph et al (2017), menjelaskan bahwa warna merah hanya mampu menembus perairan sampai pada kedalaman 35 meter dan warna kuning dapat menembus perairan sampai pada kedalaman 45 meter. Pada saat penelitian ini dilakukan, ikan target yang tertangkap berada pada kisaran kedalaman 60-70 meter, sehingga dapat disimpulkan bahwa warna merah dan kuning tidak memiliki perbedaan dalam menghasilkan jumlah hasil tangkapan.

\section{KESIMPULAN}

Berdasarkan hasil penelitian dapat diambil kesimpulan sebagai berikut :

1. Jumlah total keseluruhan hasil tangkapan yang tertangkap yaitu 10.285 ekor dengan berat keseluruhan $572 \mathrm{~kg}$

2. Perbedaan jenis umpan memberikan pengaruh terhadap jumlah hasil tangkapan. Karet pentil dominan menangkap ikan selar bentong, layang, layang ekor merah dan selar kuning, sedangkan kain kaca lebih dominan menangkap ikan kembung.

3. Warna umpan merah dan kuning tidak memberikan perbedaan yang signifikan dalam menangkap ikan pelagis kecil menurut jumlah hasil tangkapan.

\section{SARAN}

Saran yang dapat disampaikan sebagai berikut:

1. Perlu adanya penelitian mengenai warna umpan yang tepat dalam menangkap jumlah ikan selain warna merah dan kuning.

\section{UCAPAN TERIMA KASIH}

Puji dan syukur penulis panjatkan kepada Tuhan Yang Maha Esa atas segala karunia-Nya sehingga karya ilmiah ini berhasil diselesaikan. Judul yang dipilih dalam penelitian ini adalah Koreksi Ukuran Mata Pancing Rawai Tegak untuk Menangkap Ikan Pelagis Kecil di Perairan Selat Semau.

Terima kasih penulis ucapkan kepada Ibu Dr. Ir. Diniah, M.Si selaku ketua komisi Pembimbing dan Bapak Dr. Ir. Gondo Puspito, M.Sc selaku anggota komisi pembimbing yang telah memberikan saran, arahan, bimbingan dan ilmu. Bahkan lebih jauh, penulis diberikan motivasi dan rasa percaya diri untuk segera menyelesaikan studi secepat mungkin dan membantu penulis dalam memecahkan masalah-masalah selama penelitian berlangsung. Penulis tidak dapat memberikan apa-apa kecuali doa dan harapan kepada Tuhan Yang Maha Kuasa untuk selalu memberikan limpahan karunia kepada Ibu dan Bapak.

Ucapan terima kasih juga diberikan kepada KEMENRISTEKDIKTI yang telah memberi dana berupa beasiswa kepada penulis sebagai penyokong dalam studi di IPB. Kepada semua pihak yang tidak penulis sebutkan satu per satu yang telah membantu langsung atau tidak langsung, Semoga Tuhan 
Yesus membalas kebaikan tersebut dengan karunia yang berlimpah. Terakhir penulis berharap semoga karya ini bermanfaat bagi siapa saja yang membacanya, Amin.

\section{DAFTAR PUSTAKA}

Anggriawan D, Hamdhani H, Junianto, Dewanti LP. 2018. Pengaruh penggunaan warna lure light fishing terhadap hasil tangkapan ikan layur (Trichiurus sp) di Palabuhanratu. Jurnal Perikanan dan Kelautan. 9(1):71-80.

Anonim. 2011. Dinamika pembangunan Kabupaten Kupang [internet]. [diacu 2019 Januari 20]. Tersedia dari: http://studylibid.com.

Ardidja S. 2011. Usaha penangkapan ikan dengan pancing tegak. materi penyuluhan perikanan. Kementerian Kelautan dan Perikanan, Badan Pengembangan Sumberdaya Manusia Kelautan dan Perikanan, Pusat Penyuluhan Kelautan dan Perikanan. Jakarta.

Asma ST, Hismayasari IB. 2013. Pakan dan kebiasaan makan ikan kembung lelaki (Rastreliger canagurta) di perairan sekitar Sorong. Jurnal Aihara 2: 43-46

Ataupah AE. 2010. Penangkapan ikan kakap (Lutjanus sp) Di Kabupaten Kupang Propinsi Nusa Tenggara Timur. [Skripsi]. Bogor (ID): Jurusan Pemanfaatan Sumberdaya Perikanan. Fakultas Perikanan dan Ilmu Kelautan. Institut Pertanian Bogor.

Azizah N, Puspito G. 2012. Seleksi umpan dan ukuran mata pancing tegak. Marine Fisheries 3(2):169175.

[BPS] Badan Pusat Statistik Kabupaten Kupang. 2016. Laporan tahunan badan pusat statistik Kabupaten Kupang. Kupang.

Bhendarkar MP, Naik SD, Sonone AD, Wankhade HP, Joshi HD. 2014. Feeding biology of the of indian mackerel, Rastrelliger Kanagurta (Cuvier, 1817) off Ratnagiri Coast, Maharashtra, India. Journal Ecology, Environment and Conservation. 20(3):1147-1152.

Bubun RL, Simbolon D, Nurani TW, Wisudo SH. 2014. Tropik level daerah penangkapan ikan yang menggunakan light fishing di perairan Sulawesi Tenggara. Marine Fisheries. 5(1):57-66.

Hakimelahi M, Savari A, Doustshenas B, Ghodrati SM, Lewis KA. 2018. Food and feeding habits of indian mackerel (rastrelliger kanagurta) in The Southern Part Of Qeshm Island, Persian Gulf. Iranian Journal of Fisheries Sciences. DOI: 10.22092/IJFS.2018.120058.

Hulkoti SH, Shivaprakash SM, Anjanayappa HN, Somashekara SR, Benakappa S, Naik ASK, Prasad LG, Kumar J. 2013. Food and Feeding habits of mackerel Rastrelling kanagurta (Cuvier) from Mangalore Region. Journal Enviroment and Ecology. 31(2A):672-675.

Hsieh YK, Huang QB, Wu LR, Chen TC. 2001. Color effects of lures on the hooking rates of mackerel longline fishing. Fisheries Science 67:408-414.

Jayanto BB, Rosyid A, Boesono H, Faik K. 2015. Pengaruh pemberian warna pada bingkai dan badan jaring krendet terhadap hasil tangkapan lobster di perairan Wonogiri. Jurnal Saintek Perikanan 10:68-73.

Joseph SL, Macnichol EF. 2017. Color vision in fish. Scientific America. 246:140-149.

Kaswadji R, Hatta M, Umar NA. 2019. Penyusunan model untuk penangkapan berkelanjutan ikan pelagis dengan pendekatan jenjang trofik di Selat Makasar. Jurnal Natur Indonesia. 12(1):67-74. 
Kurnia M, Sudirman, Yusuf M. 2015. Pengaruh Perbedaan ukuran mata pancing terhadap hasil tangkapan pancing ulur di perairan pulau Sabutung Pangkep. Journal Marine Fisheries. 6(1):8795.

Madhavi R, Lakshmi TT. 2011. Metazoan parasites of the indian mackerel, Rastrelliger kanagurta (Scombridae) of Visakhapatnam Coast, Bay of Bengal. Journal Paracit Dis. 35(1):66-74

Paransa IJ, Wilyam R, Tipindu, Kumajas HJ (2014). Pengaruh Warna umpan buatan terhadap hasil tangkapan pancing noru di perairan Teluk Manado. Jurnal Ilmu dan Teknologi Perikanan Tangkap. 1:78-84.

Puspito G. 2009. Pancing. Buku Ajar. Departemen Pemanfaatan Sumberdaya Perikanan Fakultas Perikanan dan Ilmu Kelautan Institut Pertanian Bogor. Bogor.

Poojary N, Tiwari LR, Jaiswar AK. 2010. Food and feeding habits of the indian scad, Decapterus russelli (Ruppell, 1830) from Mumbai Waters, North-West Coast Of India. Indian Journal Fish. 57(4):9399

Pratiwi DC, Yona D, Mulyanto, Amalia YQ. 2016. Analysis of food composition of yellowstripe trevally (Selaroides leptolepis) In Paciran Waters, Lamongan, East Java. Research Journal Of Life Science. $3(2): 65-78$

Prihartini A. 2006. Analisis tampilan biologis ikan layang (Decapterus spp) hasil tangkapan purse seine yang didaratkan di PPN Pekalongan. [Tesis]. Semarang (ID): Universitas Diponegoro

Riyanto 2008. Respons penciuman ikan kerapu macan (Epinephelus fuscoguttatus) terhadap umpan buatan. [Tesis] Bogor. Institut Pertanian Bogor.

Sadhori N. 1984. Teknik Penangkapan Ikan. Bandung: Angkasa.

Siswoko P, Pramonowibowo, Fitri ADP (2013). Pengaruh perbedaan jenis umpan dan mata pancing terhadap hasil tangkapan pada pancing coping (hand line) di daerah berumpon perairan Pacitan, Jawa Timur. Journal of Fisheries Management and Technology. 2(1):66-75.

Sudirman, Mallawa. 2012. Teknik Penangkapan Ikan. Jakarta: Rineka Cipta.

Supranto J. 2001. Statistik: Teori dan Aplikasi Edisi Keenam. Jakarta: Erlangga.

Southwood A, Fritsches K, Brill R, Swimmer Y. 2008. Sound, chemical, and light detection in sea turtles and pelagic fishes: sensory-based approaches to bycatch reduction in longline fisheries. Endang Species Res 5:225-238.

Usili BH, Labaro LI, Kayadoe EM. 2015. Pengaruh umpan buatan warna merah dan kuning terhadap hasil tangkapan pancing pompa di perairan Pantai Desa Bajo, Kabupaten Minahasa Selatan. Jurnal Ilmu dan Teknologi Perikanan Tangkap 2(1):14-18.

Usman H, Akbar PS. 2008. Pengantar Statistika Edisi Kedua. Jakarta: Bumi Aksara.

Utami MNF, Redjeki S, Supriyantini E. 2014. Komposisi isi lambung ikan kembung lelaki (Raetrelliger kanagurta) di Rembang. Journal of Marine Research. 2(3):99-106. 